\title{
Motivation to Learn English: Why Indonesian Adult Learners Join a Community of Interest
}

\author{
Nurhapsari Astriningsih and Concilianus Laos Mbato \\ Master's Program in English Education \\ Universitas Sanata Dharma
}

\begin{abstract}
The importance of having a mastery of the English language has motivated language students to learn, not only in class, but also through other informal extra-curricular activities. One of these activities is gathering together in communities of interest. Motivation has been proven to have an impact on the success of learners in organizing their language-learning activities. Via Likert-scale questionnaires and semi-structured interviews, this study has examined motivation towards the study of English amongst members of a community of interest in Yogyakarta, Indonesia. The participants in this study were 85 English language club members, studying across a number of fields in several Yogyakarta universities. Six participants were then chosen for interview. On the basis of quantitative and qualitative analysis, these learners showed a high level of motivation in all aspects, with slight dominance for intrinsic and instrumental motivation. The research offered implications for further study.
\end{abstract}

Keywords: intrinsic, extrinsic, integrative, instrumental, motivation

Pentingnya penguasaan bahasa Inggris telah memotivasi pembelajar bahasa untuk belajar tidak hanya di dalam kelas namun juga melalui kegiatan - kegiatan lain di luar kelas formal. Salah satunya adalah dengan bergabung di komunitas minat. Motivasi telah terbukti memiliki dampak besar pada seberapa sukses pembelajar mengatur kegiatan belajar bahasa mereka. Melalui kuesioner skala Likert dan interview semi-terstruktur, studi ini meneliti motivasi dalam pembelajaran bahasa Inggris yang dimiliki oleh para anggota sebuah komunitas minat di Yogyakarta, Indonesia. Partisipan studi ini adalah 85 anggota klub bahasa Inggris yang menempuh studi di berbagai jurusan di beberapa universitas di Yogyakarta. Enam partisipan dipilih untuk diinterview. Berdasarkan analisis data kuantitatif dan kualitatif, para pembelajar tersebut menunjukkan motivasi yang tinggi dalam semua aspek, dengan sedikit dominasi pada motivasi intrinsik dan instrumental. Penelitian ini menawarkan implikasi untuk penelitian lebih lanjut.

Kata kunci: intrinsik, ekstrinsik, integratif, instrumental, motivasi

Traffic in the usage of English has continued to increase significantly every year since English has become a widely used communication tool (Seidlhofer, 2005). It is considered to be the most prestigious international language, which is taught not only in the foreign language section of education but also learned in communities of interest. The global use of English in various fields has been associated with career successes and economic opportunities (Mbato, 2013). Moreover, English has acted as a lingua franca. It functions as a liaison language among people from various language backgrounds (see Jenkins, 2006). In her meta-analysis

Correspondence concerning this article should be addressed to Concilianus Laos Mbato, Master's Program in English Education, Universitas Sanata Dharma. Mrican, Tromolpos 29, Yogyakarta 55002. E-mail: cons@usd.ac.id; nurhapsari22@gmail.com study on world versions of English, Jenkins (2006) found that speakers of English, in both European countries and some parts of East Asia generally, use English as a lingua franca because "they learn and use English more for interlingual cultural communication rather than to communicate with speakers who share their first lingua-culture" (p. 164). Since English is the most popular language in the world, it interests an increasing number of people who strive to master the language (Naghdipour, 2016).

Dornyei (2005) proposes that motivation is any effort, desire, and attitude toward learning or any other activity. It plays the role of "an essential factor in language learning acquisition, because it acts as the students' beacon to achieve their goals, desires, dreams, and aspirations" (Delgado, 2016, p. 6). In line with those views, 
Karaoglu (2008) points out that motivation has a significant role in keeping language learners striving, in the learning environment. Being well-motivated, a learner will exert every effort to gain success in the learning process. Students who have strong motivation can learn faster than those who are not motivated. Vallerand and Bissonnette (1992) call this latter condition 'amotivation', and it is strongly and negatively related to educational outcomes. Students who are at the 'amotivation' level cannot retain information, nor participate in learning activities, and this may lead to more disruptive situations. Students can be demotivated for various reasons, such as having no interest in the subject, finding the learning method not engaging, or being distracted by external forces. It has also been found that a demotivated student actually has difficulty in learning, and needs special treatment (McEown, Noels, \& Saumure, 2014).

The awareness of changes in the motivation of students towards learning usually leads to the development of strategic planning and learning activities. The strategies are strongly influenced by the metacognitive skills of students, their prior knowledge of the learning subjects, and their understanding of the context in which they are learning. The more effectively the student develops his or her behavior and environmental management planning, the higher the self-regulation level of the student (Alderman, 2004).

To accommodate the needs of adult learners in building an environment supportive of English learning, in 2002 a group of English education and literature students in Yogyakarta took the initiative of establishing an English-learning community; namely Englishopedia. The number of members of this community has been increasing from year to year, and members are not limited to English language students only, but also including those taking other majors, who join the activities mostly to improve their English-speaking skills.

Although Englishopedia is only a community of interest in which the members share a common passion for English, the learning activities are well-scheduled, because it has its own management, which organizes the programmes. A community of interest is a design community which brings together persons with a common interest from different domains, because of their shared concern in solving a particular problem (Fischer, 2001). The problem which has become the issue within this community is related to the need for the improvement of their English-speaking skills. Since the membership of this community is dominated by university students, the material generally discussed in their activities revolves around issues of education, careers, and other matters involved in the daily life of college students in general. The materials given in each meeting, then, have been developed overtime, because of the demands of members regarding the variety of themes and conversation facets which they wish to master.

Considering that the membership and activities in this learning community are basically such as not to oblige the members to participate, the researchers believed that a study, regarding their motivation to join the community, would be helpful, to facilitate the members developing their learning materials. This study differed from previous studies (e.g., Walker, Greene, \& Mansell, 2006; Anjomshoa \& Sadighi, 2015, Mbato \& Kharismawan, 2018) in that it was aimed at students who were learning English through their involvement in the community of interest. This community, unlike formal educational institutions, such as universities or colleges, and non-formal education, such as English courses, is quite relaxed in conducting its learning activities. This study was aimed at partially filling the gap in knowledge, by addressing the issue in this context. Therefore, this research was aimed at answering just one research question: "what kinds of motivation do Indonesian adult learners have in choosing to learn English by joining a community of interest?"

\section{Motivation and Language Learning}

Motivation and its influence on language learning have been investigated, and motivation is evidently considered to have a huge implication for the language learning success enjoyed by learners. Dornyei (1998) proposes that "motivation provides the primary impetus to initiate learning a second or foreign language, and later is the driving force to sustain the long and tedious learning process; indeed, all the other factors involved in second-language acquisition presuppose motivation, to some extent" (p. 117).

Active participation by students in learning English is determined by their motivation. Research shows that motivation directly affects strategies used by students in learning a second language, even after their interaction with native-speakers is over (Oxford $\&$ Shearin, 1994). Without sufficient motivation, students will not be able to achieve their learning goals, even though they may possess outstanding language abilities (Dornyei, 2005; Mbato, 2013). A study by Mbato and Kharismawan (2018) finds that Indonesian foreign-language learners have a high awareness of the benefits of learning English. This is in line with 
studies by Lamb (2004a, 2013), which found that young adolescent learners in Indonesia already demonstrate the determination to learn English independently, with or without the teachers' presence. Yet, Lamb (2004a) also argues that willingness by students to study English is not much recognized in the statemandated curricula. Lamb also found that they do indeed strive to learn English, although the learning process is not implemented systematically (2013). To facilitate students striving under such conditions, Lamb (2013) suggests the use of digital technologies, to improve future learning results.

\section{Intrinsic and Extrinsic Motivation}

Deci and Ryan (2002) proposed a Self-Determination Theory, when discussing motivation, and classified motivation based on different rationales, causes, or targets. In particular, they discussed the most basic difference between intrinsic and extrinsic motivation.

Deci and Ryan (2000) assert that intrinsic motivation refers to "doing something because it is inherently interesting or enjoyable", and extrinsic motivation refers to "doing something because it leads to a separable outcome" (p. 55). As Anjomshoa and Sadighi (2015) argue, "intrinsic motivation refers to motivation which is originated inside a person. There is no reward except the activity itself' (p. 126). As an example, someone who likes to read will spend his or her time for reading without any demand or obligation that he or she must fulfill, because he or she has his or her own willingness to find books to read. Extrinsic motivation, on the other hand, is the eagerness to participate in certain tasks in order to gain some type of known, external, reinforcement (Anjomshoa \& Sadighi, 2015, p. 126). Regarding learning activities, students generally learn in anticipation of reward, such as high marks and compliments, or from fear of punishment.

A study by Walker, Greene, and Mansell (2006) showed that intrinsically motivated students tended to remain focused on difficult learning tasks, gaining some valuable lessons from their failures. Besides this, intrinsic motivation is needed in order for students to access their internal learning capacity, which in turn enables them to gain a new understanding of themselves. Learning can be enhanced when students have the ability to combine intrinsic and extrinsic motivation. In the long term, when students are given the choice of methods for acquiring new information in their foreign languages, their intrinsic motivation will be increased. It has been proven that students' intrinsic motivation has more ability to empower students to keep on learning a foreign language, compared to extrinsic motivation (Mbato, 2013).

\section{Integrative and Instrumental Motivation}

The distinction between integrative and instrumental motivation in language learning has long been the object of research (see Gardner \& Lambert, 1972). These two types of motivation can influence the procedure and outcome of learning.

Language students have integrative motivation when they learn a language with the intention of participating in the culture of its people. As Anjomshoa and Sadighi (2015) point out, "integrative motivation means integrating oneself within a culture to become a part of that society" (p. 127). Integratively motivated students learn the language because they are interested in the people who speak the language, and their culture, or have family members who speak the language. However, in many language-learning contexts, integrative motivation has lost its exploratory power. In line with the increasing globalization of the world, it has become almost indistinguishable from instrumental motivation (Lamb, 2004b).

Meanwhile, instrumental motivation implies that the language learning is aimed at supporting a purpose, dealing with a job, or some further useful motive. Gardner (2001, p. 10) states, "there can be other supports for motivation, not directly associated with integrative motivation. Thus, there may be instrumental factors contributing to motivation, and we could label this combination of instrumental factors and motivation as instrumental motivation". Many students possess strong instrumental motivation for learning a second language. They learn a language because of practical reasons (e.g., an entrance test for college, a job requirement). Integratively motivated students learn the language in order to have a better understanding of the people speaking a particular language. Students who are less motivated, both that classed as integrative and as instrumental, of course will experience problems in the learning process (see Delgado, 2016; Siegit \& Richard, 2017).

\section{Method}

\section{Participants}

The participants in this study were 85 members of Englishopedia, whose ages ranged between 18 and 25 years. They studied at various departments in a 
number of universities across Yogyakarta. Six participants were selected to be interviewed. The considerations in selecting the participants to be interviewed was based on the results from their questionnaires about their learning motivations, those results indicating either high level, medium level, or low level motivation. Two participants were interviewed for each of these levels of motivation.

\section{Data Collection}

This study employed a mixed-method design. The mixed-method design combined both quantitative and qualitative approaches, in order to gain a better understanding of the research problems, rather than using merely a single method design, and to utilize the strengths of each approach within a single study (Ary, Jacobs, Sorensen, \& Razavieh, 2010). The researchers adapted a survey with a Likert-scale questionnaire, and employed interviews as the instrument of data collection. The questionnaire was adapted from the instrument utilized by You, Dornyei, and Csizer (2013), for their empirical study on the motivation and vision of English learners in China.

To ensure the validity and reliability of the questionnaire, an extensive pilot test was conducted in August 2018, delivered to 35 university students of an English department in Yogyakarta. The pilot test was conducted by using Google Form and WhatsApp Messenger. The final version of the questionnaire, comprising 28 items, was organized. It consisted of a 5-point Likert scale, with responses ranging from "strongly disagree" to "strongly agree", and was designed to assess variables related to each motivation. The questionnaire was divided into two parts. The first part concerned the demographic data of the participants. The second part, which consisted of 16 items, collected data about the motivation of the participants to learn English. Each type of motivation was investigated, utilizing four items. The results of the pilot test are presented in the Table 1 and Table 2.

The pilot test results show that all the items are valid and the instrument is considered reliable. The results of the reliability of motivation questionnaire were .907 (as presented in Table 2). According to Pallant (2011), a questionnaire is considered acceptable if the Cronbach's alpha is above .7 and it is preferable if the Cronbach's alpha is above .8 .

The questionnaire was translated into Indonesian. Questionnaires presented in the participants' own mother tongue can prevent difficulties and misunderstandings, and improve the quality of the data obtained
Table 1

Validity Results of the Questionnaire

\begin{tabular}{lccc}
\hline \multicolumn{1}{c}{ Components } & $\begin{array}{c}\text { Number } \\
\text { of item }\end{array}$ & Total & $\begin{array}{c}\text { Invalid } \\
\text { Number }\end{array}$ \\
\hline Intrinsic Motivation & $1,2,3,4$ & 4 & - \\
Extrinsic Motivation & $5,6,7,8$ & 4 & - \\
Instrumental & $9,10,11,12$ & 4 & - \\
Motivation & $13,14,15,16$ & 4 & - \\
\hline Integrative Motivation &
\end{tabular}

Table 2

Reliability of the Questionnaire

\begin{tabular}{cc}
\hline Cronbach's Alpha & $N$ of Items \\
\hline .907 & 16 \\
\hline
\end{tabular}

Table 3

Mean Range for Motivation

\begin{tabular}{cc}
\hline Mean Range & Interpretation \\
\hline $3.68-5.00$ & High degree of Motivation \\
$2.34-3.67$ & Moderate degree of Motivation \\
$1.00-2.33$ & Low degree of Motivation \\
\hline
\end{tabular}

(Dornyei \& Csizer, 2012). Besides administering these questionnaires, the researchers also conducted interviews in Indonesian, to obtain in-depth data and to verify the information obtained previously, through the questionnaire.

\section{Data Analysis}

In analyzing the answers to the research question, frequency analysis was employed, to determine the percentages from the responses of the participants to each item in the questionnaire. The researchers conducted descriptive statistical analysis of the quantitative data by using Statistical Package for the Social Sciences version 23 (SPSS 23). The data obtained was then allocated to the appropriate level of agreement or disagreement, using the following scale illustrated in Table 3.

The researchers also conducted an independentsample t-test to clarify the difference between intrinsic and extrinsic motivation, and instrumental and integrative motivation, was conducted. To gain a deeper degree of information about the motivation of the participants, the researchers also conducted semi-structured interviews. The researchers selected six participants, based on the distribution of the questionnaire results, namely those showing low, medium, or high levels of motivation. After the interviews, the researchers firstly transcribed the audio recordings and then 
checked the transcriptions, to verify the accuracy of their representations. Secondly, the researchers colourcoded the transcriptions, according to the statements of the participants, and categorized specific statements, according to the types of motivation involved. After that, the categorizations were discussed, to confirm the coding and to reduce personal bias; thus increasing the investigator reliability (Ary et al., 2010; Cohen, Manion, \& Marrison, 2000).

\section{Results}

The questionnaire was in the form of a Likert-scale instrument, used to investigate the motivation of the students to learn English through their involvement in Englishopedia. The researchers used SPSS descriptive data analysis to find out how the students perceived the usefulness of knowledge of English, either in the academic field, or in their daily lives. The following tables present the results of the survey, regarding the types of motivation of the participants that is intrinsic motivation (Table 4), extrinsic motivation (Table 5), instrumental motivation (Table 8), and integrative motivation (Table 9).

\section{Intrinsic and Extrinsic Motivation}

Table 4 presents the summary of the participants' intrinsic motivation levels, and Table 5 presents the extrinsic motivation levels, in learning English. The levels of the two types of motivation are then compared in Table 6 and 7, to determine which type of motivation is more dominant.

Table 4 shows that the participants' intrinsic motivation in learning English is generally high. This can be seen in the table, from the average mean score of 3.97. From the results of the statistical data in the table, it can clearly be seen that the participants were indeed interested in learning English; shown by the highest mean $(\mathrm{A} 1 ; \bar{x}=4.38)$. Statement number 2 shows that the participants also liked the process of learning English which they were undertaking (A2; $\bar{x}=4.09$ ). Although they enjoyed spending time learning English, as shown in Statement number 3 (A3; $\bar{x}=3.82)$, they prioritized learning English only a little more than learning other subjects, as shown in Statement number $4(\mathrm{~A} 4 ; \bar{x}=3.59)$. Given that the involvement of the participants in the community of interest was voluntary, and most of them were not taking English as their majors, such findings are actually very reasonable.

Table 4

Descriptive Statistics of Intrinsic Motivation

\begin{tabular}{clccc}
\hline No. & \multicolumn{1}{c}{ Intrinsic Motivation } & Mean & $S D$ & $\begin{array}{c}\text { Level of } \\
\text { Motivation }\end{array}$ \\
\hline A1 & Interest in learning English & 4.38 & .77 & High \\
A2 & Enjoyment of the actual process of learning English. & 4.09 & .70 & High \\
A3 & Time spent in learning English. & 3.82 & .85 & High \\
A4 & Concentration on learning English more than any other topic. & 3.59 & .90 & Moderate \\
& $\quad$ Mean Score of Intrinsic Motivation & 3.97 & .81 & High \\
$\bar{x}$ A & $\quad$ & & \\
\hline
\end{tabular}

Table 5

Descriptive Statistics of Extrinsic Motivation

\begin{tabular}{clccc}
\hline No. & \multicolumn{1}{c}{ Extrinsic Motivation } & Mean & $S D$ & $\begin{array}{c}\text { Level of } \\
\text { Motivation }\end{array}$ \\
\hline B1 & Willingness to travel internationally. & 4.18 & .98 & High \\
B2 & Desire for the approval of society. & 3.20 & 1.17 & Moderate \\
B3 & Improvement to academic and career achievement & 4.51 & .65 & High \\
B4 & Result of significant changes in daily activities, in the long term & 3.59 & .90 & Moderate \\
& & & & High \\
$\bar{x}$ B & Mean Score of Extrinsic Motivation & 3.87 & .93 & \\
\hline
\end{tabular}

Table 6

Group Statistics of Intrinsic and Extrinsic Motivation

\begin{tabular}{lccccc}
\hline & Motivation & $N$ & Mean & SD & Std. Error Mean \\
\hline \multirow{2}{*}{ Survey Score } & Intrinsic & 85 & 15.88 & 2.40 & .260 \\
& Extrinsic & 85 & 16.01 & 2.57 & .279 \\
\hline
\end{tabular}


The descriptive analysis of the questionnaire data was in line with the interview results, in which the participants reported that they often provided enjoyable exposure to English learning for themselves, for instance "I prefer to read the English version of a book. I enjoy it more. If it was translated into Indonesian, I wouldn't like it because sometimes the meaning sounds different." (Member 01) or "I prefer watching movies using English subtitles, entertaining myself but also learning" (Member 02).

In addition to intrinsic motivation, it was found that the participants' extrinsic motivation in learning English was high, as can be seen in Table 5.

The mean for each statement was above the neutral number (3). The desire to travel internationally greatly motivated participants to master English $(\mathrm{B} 1 ; \bar{x}$ $=4.18$ ). In addition, the participants also believed that mastery of English was considered very influential on the improvement of their academic and career achievements $(\mathrm{B} 3, \bar{x}=4.51)$. These findings were also sup- ported by the results of interviews, in which all participants stated that they had a great desire to continue their studies, both at home and abroad, and that the mastery of English was considered very important from the viewpoint of university entry requirements, or in the pursuit of a scholarship. Member 01, for example, stated "I want to get a scholarship abroad, or take part in a student exchange. The requirement for English is very high. My current English skills are still not sufficient."

Conversely, the approval of society toward the English skills of the participants was not seen as being really influential in motivating them to learn English (B2; $\bar{x}=3.20)$. This was mirrored in the interviews, where the participants expressed their beliefs, regarding the assumption that English mastery influences social status in the community does, in fact, exist, but felt that this is not particularly influential in encouraging them to learn English. This is shown by such comments as "I learn English so that I can be more com-

Table 7

The Result of Independent-Sample t-test for Intrinsic and Extrinsic Motivation

\begin{tabular}{llccccc}
\hline & & \multicolumn{2}{c}{$\begin{array}{c}\text { Levene's Test for Equality of } \\
\text { Variances }\end{array}$} & \multicolumn{2}{c}{ t-test for Equality of Means } \\
\cline { 3 - 7 } & & $F$ & Sig. & $t$ & $d f$ & $\begin{array}{c}\text { Sig. } \\
\text { (2-tailed) }\end{array}$ \\
\hline Survey Score & Equal variances assumed & .486 & .486 & -.339 & 168 & .735 \\
& Equal variances not assumed & & & -.339 & 167.150 & .735 \\
\hline
\end{tabular}

Table 8

Descriptive Statistics of Instrumental Motivation

\begin{tabular}{llccc}
\hline No. & \multicolumn{1}{c}{ Instrumental Motivation } & Mean & $S D$ & Level of Motivation \\
\hline C1 & The supposition that, as an educated person, one able to speak English. & 4.09 & .77 & High \\
C2 & Enjoyment of travelling abroad. & 4.26 & .77 & High \\
C3 & Plans to study abroad. & 4.26 & .86 & High \\
C4 & Preparation for further studies & 4.53 & .72 & High \\
& & & & High \\
\hline $\bar{x}$ C & Mean Score of Instrumental motivation & 4.29 & .78 & \\
\hline
\end{tabular}

Table 9

Descriptive Statistics of Integrative Motivation

\begin{tabular}{llccc}
\hline No. & \multicolumn{1}{c}{ Integrative Motivation } & Mean & $S D$ & Level of Motivation \\
\hline D1 & Engagement in discussions with foreign friends & 4.39 & .82 & High \\
D2 & Learning about the culture and art of English speakers. & 4.18 & .74 & High \\
D3 & Watching programmes made in English-speaking countries. & 3.59 & .85 & Moderate \\
D4 & Traveling to English-speaking countries. & 4.09 & .85 & High \\
& & & & High \\
\hline
\end{tabular}


municative, not for society's judgment" (Member 02). Besides, the questionnaire results also showed that the mastery of English is believed to bring significant changes in the participants' daily activities within the long term, even if their perceived usefulness of English mastery was not particularly great (B4, $\bar{x}=$ 3.59). This is similar to the response by Member 03, when asked how she perceived the usefulness of English in her daily activities, "I don't use it in everyday life; more for academic purposes".

To clarify the difference in intrinsic and extrinsic motivation of the participants, an independent-samples t-test was conducted. The result is shown in Table 6 and 7.

Table 6 reveals that there were few differences between intrinsic $(M=15.88, S D=2.40)$ and extrinsic motivation $(M=16.01, S D=2.57)$. The result of independent-sample t-test (as seen in Table 7) also shows that there was no significant difference in scores for intrinsic $(M=15.88, S D=2.40)$ and extrinsic motivation $(M=16.01, S D=2.57)$ with $t(168)=-.339$ and $p=.735>.05$.

\section{Instrumental and Integrative Motivation}

In order to illustrate the different levels of instrumental and integrative motivation, presented in Tables 8 and 9. The participants' instrumental and integrative motivational levels are compared in Table 10 and 11.

Similarly to those of the levels of intrinsic and extrinsic motivation of the participants, the results of the Likert-type questionnaire indicated that, in general, the levels of instrumental motivation of the participants were high. From statements $\mathrm{C} 1$ to $\mathrm{C} 4$, it maybe seen that the instrumental motivation was, in general, a strong reason for participants to learn English. Most participants reported that in their roles as university students, who are considered to be educated persons, they perceived that the mastery of English is necessary, not only for academic, but also for social, purposes $(\mathrm{C} 1 ; \bar{x}=4.09)$. These results also indicated that willingness to learn English for travelling $(\mathrm{C} 2, \bar{x}=$ $4.26)$, and for studying abroad $(\mathrm{C} 3, \bar{x}=4.26)$, is generally high. In addition, preparation for further study, both at home and abroad, also enthuses them to master English $(C 4 ; \bar{x}=4.53)$. Similarly, in the interviews, the participants said that with the various scholarships for study abroad, they were encouraged further to improve their English skills. Some participants also revealed that, by obtaining scholarships, they would have the opportunities to travel abroad, as Member 01 stated," If I get a scholarship abroad, I can use my holidays for backpacking. It would be useless if I was already there and not then going anywhere."

The survey of the integrative motivation of the participants indicated no differences in results. Amongst the four indicators, only one showed a moderate integrative motivation, that is Statement number 3, 'Watching programmes made in English-speaking countries' (D3; $\bar{x}=3.59)$. Conversely, other statements showing a willingness to be directly involved in the culture of English speaking countries (D2; $\bar{x}=4.18$, D4; $\bar{x}=4.09$ ), or directly to socialize with native speakers of English (D1; $\bar{x}=4.39)$, indicated high integrative motivation.

The results of independent-samples t-test are highlighted in Table 10 and 11 below. Table 10 shows the results of group statistics of instrumental and integrative motivation. It can be seen that instrumental motivation $(M=17.14, S D=2.38)$ has more influence on how participants perceived the usefulness of English, even though the results were only slightly higher than those for integrative motivation $(M=16.25, S D=$

Table 10

Group Statistics of Instrumental and Integrative Motivation

\begin{tabular}{lccccc}
\hline \multirow{3}{*}{ Survey Score } & Motivation & $N$ & Mean & SD & Std. Error Mean \\
\cline { 2 - 6 } & Instrumental & 85 & 17.14 & 2.38 & .258 \\
& Integrative & 85 & 16.25 & 2.38 & .258 \\
\hline
\end{tabular}

Table 11

The Result of Independent-Sample t-test for Instrumental and Integrative Motivation

\begin{tabular}{llcccccc}
\hline & & \multicolumn{2}{c}{$\begin{array}{c}\text { Levene's Test for Equality } \\
\text { of Variances }\end{array}$} & \multicolumn{2}{c}{ t-test for Equality of Means } \\
\cline { 3 - 7 } & & $F$ & Sig. & $t$ & $d f$ & $\begin{array}{c}\text { Sig. } \\
\text { (2-tailed) }\end{array}$ \\
\hline Survey Score & Equal variances assumed & .328 & .568 & 2.454 & 168 & .015 \\
& Equal variances not assumed & & & & 2.454 & 168.000 & .015 \\
\hline
\end{tabular}


2.38). The results of independent-sample t-test for both types of motivations (as seen in Table 11) reveals that there is significant differences between the participants' instrumental $(M=17.14, S D=2.38)$ and integrative motivation $(M=16.25, S D=2.3)$ with $t(168)=2.454$ and $p=.015<.05$.

The overall results show that the participants had a high level of motivation to learn English, be it intrinsic or extrinsic, instrumental or integrative motivation. Based on the comparison of results, it was found that the participants' intrinsic and extrinsic motivation are not significantly different $p=.735>.05$, but the instrumental and integrative motivation are significantly different $(p=.015<.05)$.

\section{Discussion}

Studies concerning the motivation of students to learn English have indeed frequently been conducted (e.g., Walker, Greene, \& Mansell, 2006; Mbato, 2013; Delgado, 2016). However, little research has been conducted into the motivation of students to join communities of interest, particularly in the learning context of English as a Foreign Language (EFL), for Indonesians. This study sought partially to fill the dearth of knowledge regarding the motivation of adult Indonesian learners to learn English, conducted independently in a community of interest.

Based on quantitative and qualitative data analyses, the motivation of the students was high in all its aspects. There was no significant difference between the intrinsic and extrinsic motivations of students to learn English yet the instrumental and integrative motivation are significantly different. The perception of the students regarding the benefits of English mastery was an important reason for them to learn English. In this case, they were more motivated to learn English for the instrumental values of such learning rather than due to the integrative motivations.

This finding is slightly different from those of Lamb (2004a, 2004b). His studies found that even though the instrumental and integrative motivations of Indonesian EFL learners are significantly different, they are difficult to distinguish as separate concepts. Lamb (2004a, 2004b) further proposed that in today's global world where people have more exposure to English cultures, the differences between instrumental and integrative motivations are no longer valid. In fact, people are more interested in the benefits of English for their future than to be parts of the English culture. The supposition that as an educated person, one should be able to speak English, prepare for further studies, travel or study abroad, and learn about the culture and art of English speakers made it difficult to distinguish instrumental from integrative motivation.

Nevertheless, the finding in this study supported the findings by some previous researchers. A study by Wong (2011), which involved Chinese undergraduate students in the context of ESL learning, as well as that by Al-Ta'ani (2018), which was conducted for Emirati EFL learners, suggested that the students were more influenced by instrumental rather than integrative motivation. Another study (Hong \& Ganapathy, 2017) also indicated that in English as Second Language (ESL) learning context such as in Malaysia, students are more instrumentally motivated than integratively motivated.

Other earlier researchers cited the reasons why students were more instrumentally than integratively motivated. Khan, Sani, and Abdullah (2016), in their study on 40-second year pre-university students in Pakistan, revealed that students were more motivated to study English for instrumental reasons rather than for integrative reasons. It seems that, they suggest, selfdevelopments in the short and long term motivate students more to learn English compared to factors such as interests in the English literature or culture. Similar conclusions were reached by Mbato (2013) and Mbato with Kharismawan (2018), who found that university students in Indonesia study English more for instrumental rather than for integrative reasons such as to get support for their studies both at home and abroad, and to meet the English language skill requirements needed to secure their future job.

Another reason that might influence significant differences between instrumental and integrative motivation is the role of English as a lingua franca. English as a lingua franca has become an integral part of the globalization processes and is used for communication between people from different language backgrounds (Jenkin, 2006). Given the increasingly globalized world, people nowadays can easily come into contact and have more exposure to the native Englishspeaking cultures through mass media and the internet. English has become the most used language in cyberspace. Moreover, being one of as the largest mobile internet users in the world today (see Puspitasari \& Ishii, 2016) makes Indonesian students gain an early opportunity to learn and apply English. Consequently, the differences in the use of English as foreign and second languages tend to be subtle (Christiansen, 2016). Similar findings were also highlighted by Awwad, Stapa 
and Maasum (2015) in their meta-analysis study on students' motivation and attitude toward EFL learning in particular on the effects of technological variables such as the internet and satellite television programs. Awwad, Stapa and Maasum (2015) concluded that the existence of globalization led to the emergence of a new society in which English had become the lingua franca. English learners increasingly recognize that it is not only related to certain cultural or geographic communities. These findings may explain why many EFL/ ESL learners learn English because of instrumental motivations rather than for integrative reasons as indicated by the findings in our study. We find that EFL learners who join community of interest are more motivated to learn English for economic or functional attachments such as preparation for further studies or job requirement rather than for emotional attachments like learning about the culture and art of English speakers. Results from both the questionnaire and interview analyses indicated that the orientation of students in learning English is generally to continue their studies.

It should also be stressed that the extrinsic $(M=$ $16.01, S D=2.57)$ and integrative $(M=16.25, S D=$ 2.3) motivation of students is also quite high, even though students are more instrumentally motivated. Both intrinsic and extrinsic motivation has no different influence on encouraging language learners to join community of interest. Intrinsic and extrinsic motivation played a crucial role in the decision by the Indonesian English-language learners to take part in an informal English language community. Findings by Mbato (2013) confirmed that extrinsic motivation can be turned into intrinsic motivation, as students engaged more in learning and experienced learning success. The combination of high intrinsic, extrinsic, instrumental and integrative motivation was likely to have a positive impact on students, in the regulation of their learning, since they were able to make use of both internal and external learning resources (e.g., Walker, Greene, \& Mansell, 2006, Mbato \& Kharismawan, 2018).

\section{Conclusion and Implications}

This study examined the motivation of the Indonesian adult students who joined a community of interest in Yogyakarta, Indonesia, to learn English. It provides valuable information about the types of motivation which triggered these adult learners to attempt to learn English independently. Generally, the students demonstrated high levels of intrinsic and extrinsic motivation. It was also found that students showed a high perception of both the instrumental and the integrative usefulness of knowledge of the English language. However, it should be noted that Indonesian students were more instrumentally than integratively motivated. One pedagogical implication from this finding is that English language teaching, be it at a formal or non-formal settings, should empower students to set their individual instrumental learning goals and support them to implement their learning goals regularly and consistently. Being able to set, monitor and evaluate their instrumental learning goals will help students to keep themselves motivated to learn English even when they are supervised to do so. This will in turn make learning a rewarding and successful experience.

The findings in this study also suggest that nonformal education centres, such as communities of interest, can provide powerful means for adult learners to conduct independent language learning activities. Communities of interest facilitate them meeting other similarly-minded people, and sharing the languagelearning experiences, without being restricted too much by such rigid curriculum demands as those found in formal educational settings. By joining communities of interest, learners of English as a foreign language (EFL) can support each other in learning the English language, primarily as regards speaking skills. In addition, a high motivation to learn English independently, which may not be fully accommodated in formal educational settings, may be developed at these communities. Non-formal language learning centres, such as communities of interest, provide more space for EFL learners to prepare their learning materials independently, and actively to participate in learning, in accordance with their needs and interests. The freedom to learn English independently may have a positive impact on the motivation to initiate, join and develop communities of interest of adult learners.

This study, however, had several limitations. Firstly, the findings could not be generalized over all of the English language communities of interest in Indonesia, since the members of the subject community have varied educational backgrounds. Secondly, this study did not explore how these students regulated their motivation. Further studies on similar issues, in different contexts, are needed, to discuss the relationship between the motivation types and the academic levels of students, and their English language proficiency. Additional research may need to focus on the motivating strategies of teachers, and how these strategies have an impact on the language learning of students. 


\section{References}

Alderman, M. K. (2004). Motivation for achievement: Possibilities for teaching and learning (2nd ed.). Mahwah, New Jersey: Lawrence Erlbaum Associate.

Al-Ta'ani, M. H. (2018). Integrative and Instrumental Motivations for Learning English as a University Requirement among Undergraduate Students at Al-Jazeera University/Dubai. International Journal of Learning and Development, 8(4), 89-105. https:// doi.org/10.5296/ijld.v8i4.13940

Anjomshoa, L., \& Sadighi, F. (2015). The importance of motivation in second language acquisition. International Journal on Studies in English Language and Literature, 3(2), 126-137. Retrieved from https:// www.arcjournals.org/pdfs/ijsell/v3-i2/12.pdf

Ary, D., Jacobs L. C., Sorensen, C., \& Razavich, A. (2010). Introduction to research in education (8th ed.). Wadsworth: Cengage Learning.

Awwad, S. A., Stapa, S. H., \& Maasum, T. N. (2015). Impact of Globalization and Technological Advancement on EFL Learners' Motivation and Attitude. International Journal of English and Education, 4(2), 277-283. Retrieved from http://ijee.org/yahoo _site_admin/assets/docs/27.87102830.pdf

Christiansen, T. (2016). The Internet as a global speech community towards plurilingualisms and english Lingua Franca. Lingue Linguaggi, 19(2016), 7796. https://doi.org/10.1285/i22390359v19p77

Cohen, L., Manion, L., \& Morrison, K. (2000). Research methods in education (5th ed.). New York, NY: Routledge Falmer.

Deci, L. E., \& Ryan, R. M. (2000). Intrinsic and extrinsic motivation: Classic definitions and new directions. Contemporary Educational Psychology, 25(1), 54-67. https://doi.org/10.1006/ceps.1999.1020

Deci, L. E., \& Ryan, R. M. (2002). Handbook of self-determination research. Rochester, NY: The University of Rochester Press.

Delgado, Don A. G. (2016). Survey study of integrative and instrumental motivation in English language learning of first-year students at Naresuan University International College (NUIC), Thailand. Proceeding of The 6th International Conference on Language, Education, and Innovation. Retrieved from https:// proceedings.icsai.org/6iclei/6iclei-003.pdf

Dornyei, Z. (1998). Motivation in second and foreign language learning. Language Teaching, 31(3), 117135. https://doi.org/10.1017/S026144480001315X

Dornyei, Z. (2005). The psychology of the language learner: Individual differences in second language acquisition. Mahwah, NJ: Lawrence Erlbaum Associates.
Dornyei, Z., \& Csizer, K. (2012). How to design and analyze surveys in second language acquisition research. In A. Mackey \& S. M. Gass, Research methods in second language acquisition: A practical guide (1st ed., pp.74-94). New Jersey, NJ: Blackwell Publishing Ltd.

Fischer, G. (2001). Communities of interest: Learning through the interaction of multiple knowledge systems. Proceedings of the 24th IRIS Conference, 2001. Retrieved from http://home.himolde.no/ molka /in765/Communities-of-Interest.pdf; http://13d.cs.co lorado.edu/ gerhard/papers/iris24.pdf

Gardner, R., \& Lambert, Z. (1972). Motivation and attitudes in second language learning. Rowley, MA: Newbury House.

Gardner, R. C. (2001). Language learning motivation: The student, the teacher, and the researchers. Texas Papers in Foreign Language Education, 6(1), 1-18. Retrieved from https://files.eric.ed.gov/fulltext/ED 464495.pdf

Hong, Y. C., \& Ganapathy, M. (2017). To Investigate ESL Students' Instrumental and Integrative Motivation towards English Language Learning in a Chinese School in Penang: Case Study. English Language Teaching, 10(9), 17-35. https://doi.org/ 10.5539/elt.v10n9p17

Jenkins, J. (2006). Current perspective on teaching world Englishes and English as a lingua franca. TESOL Quarterly, 40(1), 157-181. https://doi.org/10.2307/ 40264515

Karaoglu, S. (2008). Motivating language learners to succeed. Retrieved from http://www.tesol.org/read -and-publish/journals/other-serial-publications/com pleat-links/compleat-links-volume-5-issue-2-(june2008)/motivating-language-learners-to-succeed

Khan, T. J, Sani, A. M., \& Abdullah, S. S. (2016). Exploration of instrumental and integrative motivation for reading english as a second language among second year pre-university students of government MAO College, Lahore (Pakistan). Open Journal of Social Sciences, 2016(4), 69-76. https://doi.org/10. 4236/jss.2016.44010

Lamb, M. (2004a). 'It depends on the students themselves': Independent language learning at an Indonesian state school. Language, Culture and Curriculum, 17(3), 229-245. https://doi.org/10.1080 /07908310408666695

Lamb, M. (2004b). Integrative motivation in a globalised world. System, 32(1), 3-19. https://doi.org/j.system. 2003.04.002

Lamb, M. (2013). 'Your mum and dad can't teach you?': Constraints on agency among rural learners of English 
in the developing world. Journal of Multilingual and Multicultural Development, 34(1), 14-29. https:// doi.org/10.1080/ 01434632.2012.697467

Mbato, C. L. (2013). Facilitating EFL learners' selfregulation in reading: Implementing a metacognitive approach in an Indonesian higher education context. Lismore, NSW: Southern Cross University ePublications @SCU.

Mbato, C. L., \& Kharismawan, P. Y. (2018). A correlational study between language attitudes and English language orientation of Indonesian EFL learners. LEARN Journal, 11(1), 150-169. https:// doi.org/10.1111/j.1467-1770.1994. tb01113.x.

McEown, M. S., Noels, K. A., \& Saumure, K. D. (2014). Students' self-determined and integrative orientations and teachers' motivational support in a Japanese as a foreign language context. System, 45 (1), 227-241. https://doi.org/10.1016/j.system.2014.06.001

Naghdipour, B. (2016). English writing instruction in Iran: Implications for second language writing curriculum and pedagogy. Journal of Second Language Writing, 32(2016), 81-87. https://doi. org/10.1016/j.jslw.2016.05.001

Oxford, R., \& Shearin, J. (1994). Language learning motivation: Expanding the theoretical framework. Modern Language Journal, 78(1), 12-28. https:// doi.org/10.1111/j.1540-4781.1994.tb02011.x

Pallant, J. (2011). Survival manual: A step by step guide to data analysis using SPSS (4th ed.). Australia: Allen \& Unwin.

Puspitasari, L., \& Ishii, K. (2016). Digital divides and mobile Internet in Indonesia: Impact of smart phones. Telematics and Informatics, 33(2), 472483. https://doi.org/10.1016/j.tele.2015.11.001

Seidlhofer, B. (2005). English as a Lingua Franca. ELT Journal, 59(4), 339-341. https://doi.org/10. 1093/elt/cci064

Siegit, L., \& Richard, H. (2017). Self-regulation of learning in practice behavior: Exploratory observation study of Indonesian young badminton players. Anima Indonesian Psychological Journal, 32(4), 187-200. https://doi.org/ 10.24123/aipj.v32i4.850

Vallerand, R. J., \& Bissonnette, R. (1992). Intrinsic, extrinsic, and amotivational styles as predictors of behavior: A prospective study. Journal of Personality, 60(3), 599-620. https://doi.org/10.1111/j.1467-64 94.1992.tb00922.x

Walker, C. O., Greene, B. A., \& Mansell, R. A. (2006). Identification with academics, intrinsic/ extrinsic motivation, and self-efficacy as predictors of cognitive engagement. Learning and Individual Differences, 16(1), 1-12. https://doi.org/10.1016/ j.lindif.2005.06.004

Wong, Y. M. (2011). A study of instrumental and integrative motivations as factors influencing UTAR third-year Chinese undergraduates in learning ESL [Unpublished: A research project submitted in partial fulfillment of the requirements for the bachelor of arts (hons) english language]. Tunku Abdul Rahman, University, Faculty of Arts and Social Science.

You, C., Dornyei, Z., \& Csizer, K.(2013). Motivation, vision, and gender: A survey of learners of English in China. Language Learning, 66(1), 94 - 123. DOI: 10.1111/lang. 12140 